\title{
BŁĘDY (ORTO)GRAFICZNE \\ W ROSYJSKOJĘZYCZNYCH WIADOMOŚCIACH \\ PRZESYŁANYCH NA KARTACH POCZTOWYCH
}

\author{
(ORTHO)GRAPHIC ERRORS IN RUSSIAN POSTCARD MESSAGES
}

\section{DANIEL DZIENISIEWICZ}

\begin{abstract}
AвSTRACт. The aim of the article is to analyse orthographic errors in Russian postcard messages from the second half of the $20^{\text {th }}$ century. Nearly 240 orthographic errors retrieved from a corpus consisting of approximately 1000 Russian postcards have been classified and examined. The results of the study present the most common mistakes occurring in this type of correspondence.
\end{abstract}

Keywords: orthography, orthographic errors, postcards, Russian

Daniel Dzienisiewicz, Uniwersytet im. Adama Mickiewicza w Poznaniu, Poznań - Polska, dzienis@amu.edu.pl

ORCID ID: 0000-0003-0400-5143

\section{Wprowadzenie}

Zgodnie z definicją zamieszczoną w pracy Современный русский ^итературный язык, termin ortografia określa „system zasad pisowni wyrazów”. Jak zauważają autorzy ww. pracy, ortografia (ros. opфограффия) i zasady pisowni (ros. правописание) nie są tożsame, gdyż drugie pojęcie odnosi się do szerszego spektrum zjawisk, obejmujących m.in. także interpunkcję [Лекант 1996: 145]. Rosyjska ortografia oparta jest na trzech podstawowych zasadach: 1) morfologicznej (zakładającej jednakową pisownię morfemów, niezależną od wymowy, zob. np. zapis wyrazów дом, домашний і домовой), 2) fonetycznej (zob. np. dwa warianty pisowni prefiksów zakończonych na spółgłoskę 3: przez 3 przed literami oddającymi spółgłoski dźwięczne oraz przez $c$ przed literami oddającymi spółgłoski bezdźwięczne, por. np. беззубый - бессердечный, изгнать - испить, разбить - распилить) oraz 3) tradycyjnej, tj. historycznym zapisie wyrazów, którego nie można uzasadnić przy pomocy zasady morfologicznej bądź fonetycznej (np. pisownia wyrazów корова, собака, топор) [Кайдалова, Калинина 1983: 4].

W literaturze przedmiotu przedstawiane są różnorodne typologie błędów ortograficznych. W tym miejscu można przytoczyć np. podział na błędy or- 
tograficzne właściwe (ros. собственно орфографические очибки), błędy fonetyczno-ortograficzne (ros. фонетико-орфрографические ошибки) i błędy gramatyczno-ortograficzne (ros. грамматико-орфографические ошибки) [Пенкина, Коваленко 2016: 166, zа Иванова 2011]. Inna klasyfikacja została zaproponowana przez N. S. Rożdiestwienskiego, który wyodrębnił odpowiednio: 1) błędy graficzne, takie jak pominięcie, zamiana, przestawienie bądź wstawienie liter lub sylab; 2) błędy ortograficzne, tj. błędy naruszające zasady pisowni oddającej wymowę; 3) błędy w zapisie wyrazów w sposób łączny, rozdzielny oraz przy użyciu łącznika; 4) błędy w pisowni wielkich i małych liter; 5) błędy w podziale wyrazów przy przenoszeniu do następnego wiersza [Пенкина, Коваленко 2016: 166]. Warto zauważyć, iż duże podobieństwo do powyższej typologii błędów cechuje klasyfikację działów ortografii przedstawioną w pracy Современныи русский литературный язык, zgodnie z którą dziedzina ta obejmuje zasady określające 1) przekazywanie fonemowego składu wyrazów przy pomocy liter; 2) pisownię wyrazów i ich części w sposób łączny, rozdzielny oraz za pomocą łącznika; 3) użycie wielkich i małych liter; 4) dzielenie wyrazów przy przenoszeniu do następnego wiersza; 5) pisownię skrótowców [Лекант 1996: 146].

Literatura poświęcona ortografii języka rosyjskiego dotyczy różnorodnych aspektów tej dziedziny. Oprócz prac stanowiących wykładnię norm ortograficznych współczesnego języka rosyjskiego [zob. np. Розенталь 1970; Cwejman, Torzecka 1981; Кайдалова, Калинина 1983; Иванова 1991] należy wymienić m.in. pozycje poświęcone związkom kompetencji językowej z umiejętnością poprawnej pisowni [Щербакова 2015], błędom popełnianym przez uczniów w procesie przyswajania zasad ortograficznych [Шапирова 2013], doskonaleniu sprawności uczniów w zakresie poprawnej pisowni [Алгазина 1987; Останина 2015; Пенкина, Коваленко 2016] oraz strategiom zwalczania złych nawyków ortograficznych [Вохмина 2015]. Nawet pobieżny przegląd przytoczonych tekstów pozwala wysnuć wniosek, iż przede wszystkim skupiają się one na błędach popełnianych w nadzorowanych sytuacjach szkolnych, tj. podczas wykonywania prac pisemnych, takich jak wypracowania lub dyktanda przeprowadzane na lekcjach języka rosyjskiego. Niekiedy uwaga badaczy koncentruje się także na tekstach tworzonych w spontanicznych, niedozorowanych sytuacjach, które odzwierciedlają nawyki ortograficzne występujące w naturalnej praktyce komunikacyjnej użytkowników języka (zob. np. egzemplifikacje błędów ortograficznych zaobserwowanych w tekstach zamieszczanych na portalu społecznościowym ВКонтакте w pracy Aleksiewej [2014] oraz stanowiące celowy zabieg komunikacyjny wypadki nieprzestrzegania zasad ortograficznych w tekstach reklamowych w pracy Kryłowa [2015].

Interesującym typem tekstów w kontekście badań nad nawykami ortograficznymi jest korespondencja listowna, mogąca ukazać błędy najczęściej 
popełniane przez osoby uczestniczące w tego rodzaju komunikacji. Możliwości prowadzenia kompleksowych analiz na dużej liczbie tradycyjnych listów (tj. pisanych odręcznie) pochodzących od różnych autorów są jednak ograniczone ze względu na trudności związane ze zgromadzeniem obszernego zasobu tego typu tekstów. Łatwiejszy do pozyskania materiał dla badaczy korespondencji stanowią karty pocztowe, które można nabyć np. w antykwariatach oraz za pośrednictwem portali społecznościowych, na których funkcjonują grupy filokartystów, tj. miłośników pocztówek, zajmujących się ich wymianą i sprzedażą ${ }^{1}$. Pocztówki bowiem, w odróżnieniu od listów, na ogół nie są przesyłane $\mathrm{w}$ zapieczętowanych kopertach, a ich treść jest jawna, co wymusza na autorach wiadomości tworzenie tekstów o mniej intymnym charakterze. Być może jawność treści wpływająca na mniejszą poufność tekstów jest przyczyną szerszej dostępności kart pocztowych. Prawdopodobieństwo przeczytania wiadomości przez osoby z zewnątrz może również sprawiać, że ich treść często przyjmuje postać skonwencjonalizowanych formuł (zwrotów do adresata, życzeń, pozdrowień itp.), od których odstępstwa spotykane są jedynie okazjonalnie. Por. poniższe przykłady odtwarzalnych formuł stanowiących fragmenty autentycznych wiadomości zaczerpniętych ze zgromadzonego korpusu kart pocztowych (tu i dalej pisownia oryginalna):

1) Уважаемая Людмила Петровна!

2) Уважаемая Мария Федоровна!

3) Желаем вам всем крепкого здоровья, бодрости, успехов в труде и хорошего настроения.

4) Желаем вам здоровья, счастья, успехов в труде и учебе.

5) Целуем Рая, Наташа

6) Обнимаем, крепко целуем М и Ю.

Niniejszy artykuł ma na celu analizę 239 błędów ortograficznych zaobserwowanych w treści ok. 1000 rosyjskojęzycznych wiadomości przesłanych za pośrednictwem kart pocztowych w latach 1945-2000. Należy przy tym zaznaczyć, iż za błędy ortograficzne uznajemy wszelkie odstępstwa od normy ortograficznej literackiego języka rosyjskiego, w tym cechy charakterystyczne dla dialektów, które ujawniły się w badanym materiale. Zaliczyć można do nich np. oddawanie tzw. ikania w zapisie jednostki тибе. Ikanie (ros. иканъе) to typ wokalizmu stanowiący podstawę wymowy literackiej i występujący w gwarach centralnych (obwód moskiewski) oraz na terenach położonych na zachód i wschód od Moskwy (obwody twerski i uljanowski), w którym samogłoski /'A/, /'O/ i /'E/ w pierwszej sylabie przedprzyciskowej wymawiane są jako [и] [Малахов 2013: 20]. Innym przykładem odstępstwa od

\footnotetext{
${ }^{1}$ Zob. np. stronę https://vk.com/filokartiya (dostęp 19.09.2017).
} 
normy jest zapis końcówki fleksyjnej $-y$ w formie dopełniacza rzeczownika rodzaju męskiego ycnexy. Pomimo że forma ta jest dopuszczana jako wariant w języku literackim, ta końcówka fleksyjna najczęściej występuje w gwarach południowych [Малахов 2013: 39]. Jako błąd ortograficzny potraktowano również formę miejscownika жизне. Końcówka -e stanowi wynik paralelizmu form przypadków spowodowany oddziaływaniem paradygmatu pierwszej deklinacji na trzecią. Jest to zjawisko charakterystyczne dla wschodniej części narzecza południoworosyjskiego i sąsiadujących z nim gwar środkoworosyjskich [Малахов 2013: 40].

Fakt występowania w wiadomościach odtwarzalnych formuł (a co za tym idzie, również fakt powtarzalności poszczególnych wyrazów wchodzących w ich skład) umożliwi poznanie praktyk ortograficznych nadawców oraz pozwoli określić, jakie błędy powtarzają się najczęściej w tego typu tekstach. Badania nad odstępstwami od zasad ortograficznych właśnie w wiadomościach zapisywanych na kartach pocztowych nie wydają się bezzasadne, gdyż nawet pobieżna analiza wybranych tekstów pokazuje, iż istotnie można zaobserwować w nich liczne błędy, por. następujące przykłady:

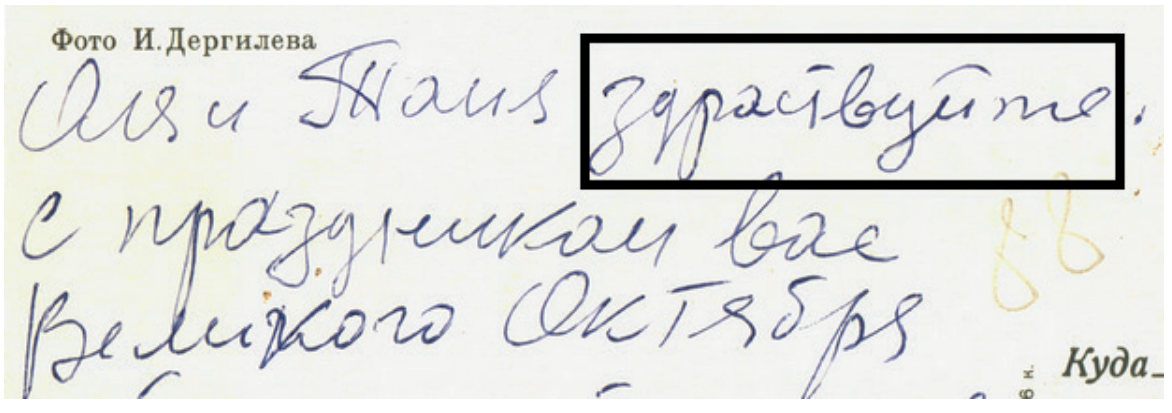

Fot. 1. Błąd ortograficzny w tekście zamieszczonym na karcie pocztowej (pominięcie litery $b \mathrm{w}$ zapisie wyrazu здравствуüme)

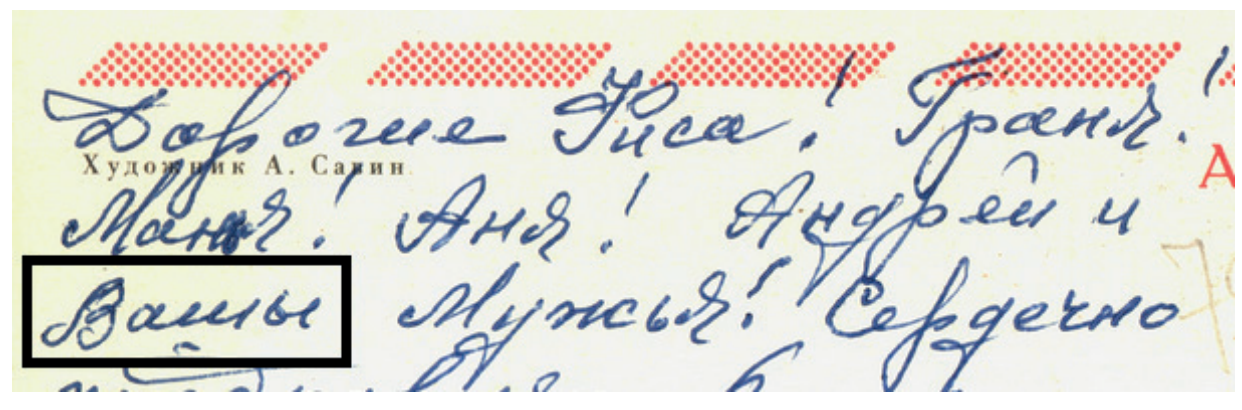

Fot. 2. Błąd ortograficzny w tekście zamieszczonym na karcie pocztowej (zapis końcówki fleksyjnej zaimka dzierżawczego Bawu za pomocą litery 
Dotychczas badano pewne aspekty języka wiadomości przesyłanych za pośrednictwem kart pocztowych, warto zatem dokonać przeglądu niektórych prac poświęconych tej tematyce. Uwaga badaczy skupiała się przede wszystkim na (relatywnie) stałych połączeniach wyrazowych występujących w wybranych elementach struktury wiadomości przekazywanych wśród pracowników różnych instytucji, tj. zwrocie do adresata oraz formule życzeń [Немчинова 2008]. Badano również teksty życzeń skierowanych do osób piastujących stanowiska rektora, dziekana, lekarza naczelnego oraz do przedsiębiorcy z okazji Nowego Roku, urodzin, Dnia Obrońcy Ojczyzny (23 lutego) i Dnia Kobiet (8 marca). Zaobserwowano, iż wartości występujące w treści życzeń różnią się w zależności od płci adresata [Немчинова 2012]. Ponadto analizowano formuły występujące $\mathrm{w}$ niemieckojęzycznych wiadomościach, wykazując wysoką częstość użycia klisz pragmatycznych. Autorka badania odnotowała formuły odtwarzane w zależności od takich okoliczności, jak urodziny, narodziny dziecka, Święta Bożego Narodzenia, Nowy Rok, ślub i konfirmacja [Низеева 2014]. Nie poświęcano dotąd jednak uwagi zagadnieniom (nie)poprawności pisowni w tekstach wiadomości zamieszczanych na pocztówkach, co ponownie daje asumpt do podjęcia badań w obrębie tej tematyki.

\section{Analiza materiału badawczego}

Błędy ortograficzne występujące $\mathrm{w}$ wiadomościach przesyłanych za pośrednictwem kart pocztowych skategoryzowano w oparciu o zmodyfikowaną wersję typologii opisanych we wprowadzeniu do niniejszego artykułu [Пенкина, Коваленко 2016: 166; Лекант 1996: 146]. Zaobserwowane w tekstach wypadki niepoprawnego zapisu przyporządkowano do pięciu kategorii, obejmujących błędy:

1) polegające na zastępowaniu, dopisywaniu oraz opuszczaniu liter,

2) w pisowni rozdzielnej, łącznej oraz w stosowaniu łącznika,

3) w pisowni wielkich i małych liter,

4) w podziale wyrazów przy przenoszeniu do następnego wiersza, a także

5) błędy graficzne prowadzące do naruszania poprawności składniowej połączeń wyrazowych.

Pewne zastrzeżenia może budzić kategoria 1, obejmująca wypadki zastępowania, dopisywania i opuszczania liter, nieuwzględniająca fonetycznych i gramatycznych aspektów znajdujących się u podstaw sklasyfikowanych w jej ramach błędów. Należy jednak zaznaczyć, że ten strukturalny podział funkcjonuje jedynie jako kategoria nadrzędna, zaś informacje dotyczące charakteru poszczególnych błędów zostały umieszczone osobno w konkluzji analiz. 


\subsection{Błędy polegające na zastępowaniu, dopisywaniu i opuszczaniu liter}

Jak odnotowano powyżej, zaobserwowane błędne zapisy liter podzielono na trzy podkategorie, obejmujące wypadki zastępowania, dopisywania oraz opuszczania liter. Należy w tym miejscu zwrócić uwagę, że podziału na morfemy dokonano za pracą [Тихонов 1985], a zastąpione, dopisane i pominięte litery zostały wyróżnione przy pomocy pogrubionej czcionki. W nawiasach okrągych przytoczono poprawny zapis, natomiast $\mathrm{w}$ nawiasach kwadratowych podano ogólną liczbę wystąpień poszczególnych form graficznych wyrazów (jeśli wystąpiły w materiale częściej niż raz). Pominięte litery zostały zaś dopisane $w$ nawiasach $w$ pozycjach, $w$ których występują $w$ poprawnym zapisie analizowanych wyrazów. Ponadto wielkość liter jest zgodna z oryginalnymi zapisami zamieszczonymi na kartach pocztowych. Poniżej omówiono błędy wchodzące w skład wyodrębnionych grup.

\subsubsection{Zastępowanie liter}

Łącznie w badanym materiale stwierdzono obecność 77 błędów polegających na zastępowaniu liter występujących $w$ poprawnym zapisie wyrazów przez inne litery. Odchylenia tego typu zaistniały w pisowni przedrostków zaimków przeczących, w których zaobserwowano zapis partykuły не w miejsce partykuły ни: zob. jednostki не кому (никому) oraz нечего (ничего). Ponadto można wskazać błędy w pisowni rdzeni rzeczowników: Здарове (Здоровъе), здаровъя [5] (здоровья), здаровя (здоровья), здоровия (здоровья), обояние (обаяние), щуастя (счастья); przymiotników: атличного (отличного), гловноя (главная), жыьы (живы), наилутшего (наилучшего), обоятельной (обаятельной), семеиного (семейного), харамего [3] (хорочего), харашего [3] (хорошего), харомего [2] (хоромего); przysłówków: облично (отлично), щзаслива (счастливо); czasowników: дектуют (диктуют), жилаим (желаем), заидешь (зайдешъ), отплотят (отплатят), Поздровляем [2] (Поздравляем), Поздровляю (Поздравляю), Праздравляю (Поздравляю), пробиии (пробыли); zaimka тибе (тебе); przyimka am (om); oraz partykuły ни (не). Odnotowano także błędy występujące $\mathrm{w}$ zapisie sufiksów rzeczowników: благополучея (благополучия), плаваньи (плавании); przysłówków: долга [2] (долго), многа (много), наверна (наверно), побольши (побольше); oraz czasownika (w formie imiesłowu): ^юбищее (любямие). Ostatnią grupę stanowią wypadki niepoprawnego zapisu końcówek fleksyjnych rzeczowników: $b$ жизне (в жизни), в учеби (в учебе), досвидане (до свидания), мечти (мечты), Танечки (Танечке), успеху (успеха); zaimków: твойм (твоем), Вашы (Ваши), всево (всего), которои (которые), самова (самого); przymiotników: гловноя (главная), Дорогаю (Дорогая), крепкога (крепкого), лучшива (лучшего), лучшива (лучшего), лучшива (лучшего), много уважаемаи (многоуважаемой), хорошаво (хоро- 
шего), хорошва (хоромего), хорошыва [2] (хоромего); oraz czasowników: будим (будем), Желая (Желаю), жилаим (желаем), ююбищее (ююбяие), обнимая (обнимаю), оставиевся (оставшейся), По цеелуите (Поцелуйте), получи (получу), Приежаите (Приезжайте).

\subsubsection{Dopisywanie liter}

Analiza materiału ujawniła 12 błędów polegających na dopisywaniu liter niewystępujących w poprawnym zapisie badanych wyrazów. Zaobserwowano odstępstwa polegające na dodawaniu liter $w$ zapisie rdzeni rzeczowników: Анъя (Аня), встречъ (Встреч); czasowników: Праздравляю (Поздравляю), приеждайте (приезжаите), Приймите (Примите), проведвать (проведать), Проздравляем (Поздравляем), Проздравляю (Поздравляю); oraz wykrzyknika: Вздравствуйте (Здравствуйте). Ponadto stwierdzono wypadki dodawania miękkiego znaku $\mathrm{w}$ zapisie sufiksu -uน $\mathrm{w}$ formach mianownika imion odojcowskich Васильевичъ (Васильевич) і Сергеевичъ (СергееВич), jak również litery $e \mathrm{w}$ pisowni sufiksu -знь w wyrazie жизень (жизнъ).

Na szczególną uwagę zasługuje trzykrotny zapis czasownika поздравлять z dodatkową literą $p$ : Праздравляю, Проздравляем, Проздравляю. Mоżna założyć, iż stanowi on celowy zabieg humorystyczny, zainspirowany odcinkiem popularnego serialu animowanego Винни-Пух pt. Винни-Пух и денъ забот, $\mathrm{w}$ którym forma ta występuje $\mathrm{w}$ jednej $\mathrm{z}$ wypowiedzi ${ }^{2}$. Niewykluczone jednak, iż należałoby odwołać się $w$ tym przypadku wyłącznie do faktora stylistycznego, gdyż forma проздравлять ma charakter potoczny (просторечие).

\subsubsection{Opuszczanie liter}

Częstszą praktykę niż dopisywanie stanowi pomijanie liter - wykryto bowiem 42 tego typu błędne zapisy, wśród których należy wymienić pominięcie litery $c \mathrm{w}$ pisowni prefiksu przysłówka бе(c)счетно oraz liter występujących w rdzeniach form rzeczowników: бол(b)нице, груn(n)y, дмитр (и)евна, досви-

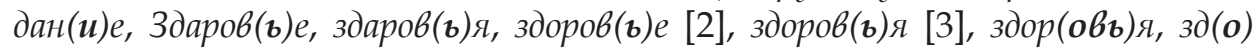
ров(b)я, комис(c) ия, Поздрав(л)еня, счаст(b)я [3]. Warto zwrócić uwagę na powtarzające się problemy z pisownią rzeczowników здороb(b)e oraz cuacm(b) $e$, polegające na pomijaniu miękkiego znaku, jak również na fakt niezapisywania liter oddających podwójne spółgłoski w wyrazach гpyn(n)a i комис(c) ия. Odnotowano także wypadki pominięcia niewymawianych liter w zapisie przymiotnika праз(д)ничного, czasowników Прие(з)жаите, прие(з)жайте i прие(3)ждайте, wykrzykników 3дра(b)ствуй [2], здра(b)сmbyūme oraz par-

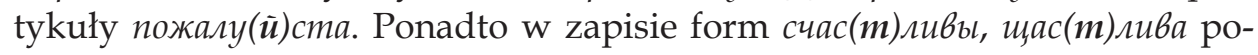

\footnotetext{
${ }^{2}$ Zob. https://www.youtube.com/watch?v=J-UHwBgvG70 (dostęp 19.09.2017).
} 
minięta została litera $m$, z kolei litera -я- - $\mathrm{w}$ zapisie jednostki поздраßл(ять). Innym interesującym typem błędów jest niezapisywanie - wszystkich bądź części - liter oddających końcówki fleksyjne rzeczowników: благополучu(я), детя(м); zaimka: невкажду(ю); przymiotników: хорош(ую), хорош(е)ва; oraz czasowników w formie bezokolicznika: ждат(в), жела(ть), переда(ть), пожелат(в), поздравл(ять), Поздравля(ть).

\subsection{Błędy w pisowni rozdzielnej, łącznej oraz w stosowaniu łącznika}

Kolejna kategoria błędów wyodrębniona $\mathrm{w}$ toku analiz obejmuje niepoprawny zapis jednostek o pisowni rozdzielnej, łącznej oraz wymagającej użycia łącznika (razem 43 błędy). Wśród wypadków łącznego zapisu wyrazów o pisowni rozdzielnej należy wskazać zapis formuły pożegnalnej Досъидания [3] (por. także jednostkę досbидане z błędnym zapisem końcówki formy dopełniacza wyrazu сьидание) oraz zapis Вобщем (В общем). Ponadto odnaleziono wypadki łącznej pisowni wyrażeń przyimkowych, por. кнам [2] (к нам) oraz Комне (Ко мне), w tym formuł życzeń i pozdrowień, takich jak сновым [3] (с Новым годом), сприветом [3] (с приветом), oraz czasowników, z którymi łącznie została zapisana partykuła не: неболеть (не болеть), незабывайте (не забывайте), неписала (не писала), неработаю (не работаю) (por. także jednostkę нистареть (не стареть) z błędnym zapisem partykuły ни w miejsce partykuły не). Zaobserwowano również zapis неbкажду (не $b$ каждую), w którym pominięta została litera

W materiale wystąpiły także błędy polegające na rozdzielnym zapisie wyrazów o pisowni łącznej. Błędy tego typu popełniono w pisowni rzeczowników i przymiotników złożonych: много летия (многолетия), Много уважаемая (Многоуважаемая), много уважаемаи (многоуважаемой), przysłówka на всегда [2] (навсегда), przymiotnika не важное (неважное) oraz przysłówków не важно (неважно) і не легко (нелегко). Niepoprawną pisownię rozdzielną odnotowano również w zapisie spójnika что бы (чтобы) oraz zaimka не кому (никомy - zob. także błędny zapis litery $e \mathrm{w}$ miejsce $u$ ). Ponad to zaobserwowano wypadek rozdzielnego zapisu prefiksu no- $\mathrm{w}$ formie trybu rozkazującego czasownika u̧еловать, tj. По ц̧елуите (Поц̧елуйme - zob. także błędny zapis litery $u$ w miejsce $\bar{u})$.

Zapis łącznika w jednostkach o pisowni rozdzielnej wystąpił wyłącznie $\mathrm{w}$ konstrukcji тем-же (тем же), natomiast zapis łącznika $\mathrm{w}$ jednostkach o pisowni łącznej zaobserwowano trzykrotnie: $\mathrm{w}$ pisowni przymiotnika между-народный (международный) oraz przysłówków по-больше (побольше) і по-крепче (покрепче).

Jeśli chodzi o rozdzielny zapis jednostek o pisowni wymagającej użycia łącznika, ujawnił się on w 7 wypadkach: w zapisie partykuły -mo w połączeniu время то (время-то), partykuły все таки (все-таки), przysłówków no 
старому [3] (по-старому) і по прежнему (по-прежнему) oraz rzeczownika 45 летием (45-летием). Z kolei łączny zapis wyrazów o pisowni wymagającej użycia łącznika ujawnił się jedynie w jednostce nостаромy [2] (по-старомy).

\subsection{Błędy w pisowni wielkich i małych liter}

Łącznie w materiale odnotowano 43 błędy w pisowni wielkich i małych liter. Jednostki, w których wystąpił błędny zapis wyrazu małą literą to przede wszystkim dwuczłonowe nazwy świąt składające się z cyfry i nazwy miesiąca, która zgodnie z regułą powinna być zapisywana wielką literą: 1e мaя [8] (1 Мая), 1ое мая [3] (1 Мая), 1го мая [2] (1 Мая), 1 мая [2] (1 Мая), 1м мая (1 Мая), 1 маем (1 Маем), 9м мая (1 Мая), 7го ноября (7 Ноября), 8 марта [4] (8 Марта), 8го марта [3] (8 Марта), ве марта (8 Марта), 8 -октября (8 Октября). Ponadto błędny zapis małą literą zaobserwowano w wielowyrazowych nazwach świąt, w których pierwszy wyraz powinien być zapisywany wielką literą: днём учителя (Днём учителя), международным женским днём (Международным женским днём), днем Победы [4] (Днем победы) [zob. Orzechowska 1994: 103]). Warto przy tym zauważyć, że w literaturze podawane są dwa odmienne sposoby zapisu nazwy święta День побеdы: w pracy [Orzechowska 1994: 103] zamieszczono informację, że tylko pierwszy wyraz powinien być pisany wielką literą, natomiast w opracowaniach [Розенталь 1970: 26; 1984: 96; 1988: 91] podano, iż oba wyrazy należy pisać wielkimi literami.

Odnaleziono również wypadki zapisu imion i imion odojcowskich małą literą: елезавета (Елизавета), игоря (Игоря), машу (Машу), тоня (Тоня), фредор (Федор), федя (Федя), дмитревна (Дмитриевна), фредорович (Федорович); natomiast zapis wielkiej litery $\mathrm{w}$ wyrazie, który powinien być zapisywany literą małą, odnotowano w nazwie miesiąca Декабря (декабря).

\subsection{Błędy w podziale wyrazów przy przenoszeniu do następnego wiersza}

Ogółem odnaleziono 43 wypadki przenoszenia wyrazów do następnego wiersza, por. позд-равляем, праздни-ком, жиз-ни, празни-чного, по-желания, послу-шнои, креп-кого, гри-бной, вку-сные, по-старо-му, ра-достным, ску-чаем, наи-лучщего, благопо-лучия, празднич-ного, семей-ного, тру-де, празд-ником, празд-ником, благо-получия, благород-ном, благополу-чия, заслу-женного, бла-гополучия, так-же, быстрей-шего, нас-троения, настро-ения, жизнен-ных, стар-ческий, ужас-но, радо-стей, настрое-ния, ста-райся, креп-кого, настро-ения, радост-ным, Тимо-феевич, Вален-тина, поже-лания, праз-дником. Jednakże po przeanalizowaniu powyższych zapisów w kontekście ich zgodności z zasadami zawartymi w literaturze przedmiotu [zob. Cwejman, Torzecka 1981: 128-131] stwierdzono, iż błędy wystąpiły jedynie w dwu wypad- 
kach podziału. Błędny podział łamiący zasadę stanowiącą o nieoddzielaniu spółgłoski od poprzedzającej ją samogłoski [Cwejman, Torzecka 1981: 128] zaobserwowano w jednostce Вел-икой (Ве-ликой lub Вели-кой). Z kolei niepoprawny podział wyrazu выз-доровления (вы-здоровления) narusza zasadę postulującą niepozostawianie nietworzącej sylaby początkowej części rdzenia przy prefiksie na końcu linii (oczywiście pod warunkiem, że cząstka bu- zostanie uznana za prefiks, gdyż taki status posiada ona w strukturze słowotwórczej czasownika motywującego rozpatrywany rzeczownik odsłowny, tj. bыздороветь) [Cwejman, Torzecka 1981: 130].

\subsection{Błędy graficzne prowadzące do naruszania poprawności składniowej połączeń wyrazowych}

Ostatnią kategorię tworzy 20 wypadków zastąpienia, dopisania i pominięcia liter, prowadzących do powstania błędów syntaktycznych. Ze względu na szczególny charakter tych odchyleń zdecydowano, iż zostaną one omówione osobno. Pierwszą grupę tworzą wypadki pomijania wyrazów obligatoryjnych dla określonych związków wyrazowych. Najczęściej obserwuje się opuszczanie przyimka $c$ występującego w konstrukcji nоздравлять $c+\mathrm{N}_{5^{\prime}}$ prowadzące do naruszania związku rządu czasownika i wyrażenia przyimkowego, por. Маму и бабушку поздравляем (c) новорождение(м) дочки и внучки; поздравл вас, (c) великим праздником октября; Поздравляем вас (c) наступающим праздником; Поздравляем (c) днем рождения; Поздравляем (c) Наступающим праздником; поздравляю Вас (c) праздником; Сердечно поздравляю тебя (c) праздником весны. Zarejestrowano również brak przyimka b w konstrukcji Желаю [...] успехов (b) mpyде.

Ponadto w materiale wystąpiły błędy prowadzące do naruszania związku zgody między wyrazem określającym i określanym w konstrukcjach imiennych. Należy w tym miejscu wskazać niepoprawnie użytą formę narzędnika przymiotnika новый w połączeniu $b$ Новым годy, wymagającym użycia formy miejscownika Hoboм. Inne przykłady naruszania związku zgody to: с наступающим Новым год(ом) (год - błąd polegający na użyciu formy $\mathrm{N}_{1}$ w miejsce $\mathrm{N}_{5}$ - годом), с наступающем женским праздником (наступающем - błąd polegający na użyciu formy $\mathrm{N}_{6} \mathrm{w}$ miejsce $\mathrm{N}_{5}$ - наступающим ), с новом, счастливым годом! (новом - błąd polegający na użyciu formy $\mathrm{N}_{6} \mathrm{~W}$ miejsce $\mathrm{N}_{5}-$ новым), с днем рождением (рождением - błąd polegający na użyciu formy $\mathrm{N}_{5}$ w miejsce $\mathrm{N}_{2}$ - рождения). Odnotowano także wypadki braku związku zgody między podmiotem a orzeczeniem: Володя у нас учиться, Гена учиться, $\mathrm{w}$ których orzeczenie występuje w formie bezokolicznika $\mathrm{w}$ miejsce formy trzeciej osoby liczby pojedynczej (уuนmcя), jak również przykłady odwrotnej praktyki: Желаю пить и веселит(в)ся Но что-б под ёлку не свалит(в)ся, желаю тебе счастья здоровья и учит(в)ся только на 4 
u 5, w których orzeczenia występują $\mathrm{w}$ formie trzeciej osoby liczby pojedynczej w miejsce form bezokolicznika (веселиться, учиться). Odnaleziono również błąd polegający na użyciu niewłaściwego przyimka: $\boldsymbol{B}$ нac bce no старому (У нас все по старому).

Liczbę oraz procentowy udział błędów wchodzących w skład poszczególnych kategorii przedstawiono w poniższej tabeli:

\begin{tabular}{|l|c|c|c|c|c|}
\hline \multicolumn{1}{|c|}{ Kategoria } & I & II & III & IV & V \\
\hline Liczba błędów & 131 & 43 & 43 & 2 & 20 \\
\hline Udział procentowy & 54,81 & 17,99 & 17,99 & 0,84 & 8,37 \\
\hline
\end{tabular}

Wynika z niej, iż w analizowanym materiale najliczniej reprezentowana jest kategoria I $(54,81 \%)$, tj. błędy polegające na zastępowaniu, dopisywaniu i opuszczaniu liter. Drugie miejsce pod względem liczebności zajmują kategorie II i III (obie stanowiące po 17,99\% całości), obejmujące odpowiednio błędy w pisowni rozdzielnej, łącznej i w stosowaniu łącznika oraz błędy w pisowni wielkich i małych liter. Kategoria V, w której skład wchodzą błędy graficzne prowadzące do naruszania poprawności składniowej połączeń wyrazowych, stanowi 8,37\% materiału, natomiast kategoria IV (błędy w podziale wyrazów przy przenoszeniu do następnego wiersza) - 0,84\%.

Badania pokazują, iż przyczyną powstawania większości odstępstw jest prawdopodobnie chęć oddawania regularnych zjawisk fonetycznych przez osoby piszące wiadomości, por. takie przypadki zastępowania liter, jak zapis litery $o \mathrm{w}$ pozycji nieakcentowanej jako $a$ (Здарове, здаровья, здаровя, атличного, харашего, харашего, харочего, долга, многа, наверна, крепкога, лучшива), zapis litery $b \mathrm{w}$ końcówkach fleksyjnych form dopełniacza przymiotników

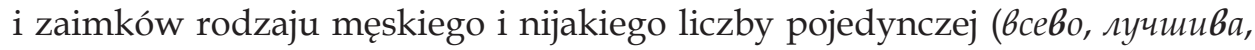
самова, хорошаво, хорошва, хорошы $а$ ), zapis litery $m \mathrm{w}$ miejsce połączenia си (щастя, щаслива) oraz zapis litery $u \mathrm{w}$ miejsce litery $e \mathrm{w}$ pozycjach bezprzyciskowych (тибе, ни, будим, жилаим, Танечки). Interesujące są również wypadki odwrotne, tj. zapis litery $a \mathrm{w}$ pozycji nieakcentowanej przy pomocy litery о (обояние, обоятельной, Поздровляем, Поздровляю, гловноя) oraz litery $u \mathrm{w}$ pozycji nieakcentowanej za pomocą litery e, ukazujące nieznajomość zapisu niektórych morfemów (благополучея, жизне, не кому, нечего, любищее zob. zasada morfologiczna). Warto odnotować, że część przytoczonych przykładów błędów ilustruje działanie form analogicznych, por. np. обоятельной (обоняние) сzу поздровляем (здоровъе). Innymi przykładami błędów spowodo- 
wanych wpływem systemowych zjawisk fonetycznych na pisownię są przypadki dopisywania liter w wyrazach Приймите і жизень.

Natomiast wypadki pomijania liter najczęściej obejmują opuszczanie miękkiego znaku, niepodwajanie spółgłosek, pomijanie niewymawianych liter oraz częściowe bądź całościowe opuszczanie końcówek fleksyjnych (w tym m.in. miękkiego znaku w końcówkach form bezokolicznika). Odnotowano także liczne wypadki łącznej pisowni partykuły не z czasownikami, przymiotnikami i przysłówkami. Błędne użycie małej litery ujawniło się zaś w dwuczłonowych nazwach świąt składających się z cyfry i nazwy miesiąca oraz w wielowyrazowych nazwach świąt, w których wielką literą powinien zostać zapisany pierwszy wyraz. Ponadto zarejestrowano wypadki zapisu małą literą imion i imion odojcowskich. Błędy w podziale wyrazów przy przenoszeniu do nowej linii mają charakter jednostkowy i spotykane są rzadko. Nielicznie reprezentowane są też błędy polegające na dodawaniu liter; trudno jednoznacznie wskazać przyczyny ich występowania, najprawdopodobniej należy złożyć je na karb potocznych nawyków mownych poszczególnych nadawców bądź też - w niektórych wypadkach - mogą stanowić one efekt celowej stylizacji tekstu. W skład błędów graficznych prowadzących do zaburzenia połączeń składniowych zaliczono takie wypadki zastępowania, dopisywania oraz pomijania liter, które naruszają związki rządu oraz zgody.

Ustalono ponadto, iż 239 błędów ortograficznych, które zostały dostrzeżone w korpusie ok. 1000 pocztówek, wystąpiło łącznie w 179 wiadomościach, a więc w ok. 17,9\% badanego materiału. Największą grupę stanowią wiadomości zawierające jednostkowe odchylenia (142). Wypadki występowania dwóch błędów w jednej wiadomości zaobserwowano w 17 tekstach, trzech - w 9, czterech - w 5, sześciu zaś - w 2. Fakt wystąpienia odpowiednio siedmiu, dziewięciu, dziesięciu oraz czternastu błędów odnotowano w pojedynczych wiadomościach. Wypadki wystąpienia ponad trzech błędów w jednym tekście odnotowano jedynie w treści 11 wiadomości, co stanowi ok. 6\% tekstów, w których zlokalizowano błędy i ok. 1,1\% wszystkich przeanalizowanych tekstów.

Oprócz tego podjęto próbę ustalenia, jakie typy błędów występują w materiale przy uwzględnieniu takich zmiennych, jak płeć nadawcy (kobieta, mężczyzna, grupa kobiet, grupa mężczyzn, grupa mieszana) oraz lokalizacja, z której wysłano wiadomość. Analiza pokazała, iż:

1) większość badanych tekstów zawierających błędy ortograficzne została napisana przez kobiety bądź grupy mieszane (wiadomości pochodzące wyłącznie od mężczyzn wystąpiły w materiale kilkukrotnie),

2) w ok. połowie badanych wiadomości nie została określona lokalizacja nadawcy. 
Ponadto analiza wiadomości pisanych przez grupy mieszane, tj. takie, w których treści widniały zarówno imiona kobiece, jak i męskie, pozwala mniemać, iż prawdopodobnie były one pisane przez kobiety, które w tekście dopisywały imiona mężczyzn połączonych z nimi relacją rodzinną. Fakt ten sprawia, iż w dużej mierze materiał jest reprezentatywny jedynie dla błędów popełnianych przez kobiety, nie dostarcza natomiast informacji na temat praktyki ortograficznej mężczyzn. Pozwala to jednak sądzić, iż pisanie wiadomości wysyłanych następnie na pocztówkach było w badanym okresie domeną kobiet. Brak informacji dotyczących lokalizacji w dużej liczbie tekstów uniemożliwia także wyciąganie wniosków o regionalnym charakterze niektórych błędów.

\section{Podsumowanie}

Charakterystyczną cechą analizowanych wiadomości jest fakt, iż często nie są poddawane drobiazgowej korekcie, stanowią zatem interesujący obiekt badawczy w kontekście naturalnych, niekorygowanych nawyków ortograficznych ich autorów. Analiza języka kart pocztowych nie jest jednak wolna od problemów. Mankament stanowi z pewnością fakt, że częstokroć trudno jest ustalić wiek, poziom wykształcenia czy narodowość nadawcy. Orientacyjne określenie wieku możliwe jest jedynie na podstawie występujących w tekście bezpośrednich zwrotów do adresata, np. Дорогая бабушка - wówczas dowiadujemy się, że nadawcą jest wnuk lub wnuczka, a adresatem babcia. W rzeczywistości jest to jednak informacja określająca typ relacji łączącej nadawcę i adresata, a nie ich wiek. Nie należy także wykluczać możliwości popełniania błędów przez nadawcę w celu takiej stylizacji tekstu, aby osiągnąć efekt komiczny. $Z$ treści wiadomości łatwiej jest natomiast wywnioskować takie parametry, jak płeć nadawcy i adresata bądź nazwę miejscowości, z której oraz do której wysłano pocztówkę (tj. informacje geograficzne, pomocne $\mathrm{w}$ ustaleniu, czy poszczególne zapisy są warunkowane czynnikami dialektalnymi), jednakże badanie przeprowadzone na zgromadzonym dotąd materiale nie pozwala na wyciągnięcie wniosków w tym zakresie i powinno być powtórzone na większej liczbie wiadomości, odpowiednio opatrzonych dokładną lokalizacją oraz uwzględniających teksty autorstwa mężczyzn. Mając na uwadze powyższe kwestie, wydaje się jednak, że przeprowadzona analiza - za sprawą przebadania relatywnie dużej liczby tekstów pochodzących od różnych autorów - pozwoliła ukazać, jakie błędy ortograficzne występują w tego typu wiadomościach najczęściej i może stanowić podstawę do przeprowadzenia badań na materiale korpusu wiadomości przesyłanych na kartach pocztowych uzupełnionym o teksty autorstwa mężczyzn oraz teksty bezwyjątkowo opatrzone dokładną lokalizacją. 
Materiał poddany analizie $\mathrm{w}$ niniejszej pracy pochodzi z zakończonego okresu historycznego, trudno zatem stwierdzić, czy - oraz z jaką częstością zaprezentowane błędy występują $\mathrm{w}$ tekstach tworzonych przez użytkowników języka rosyjskiego obecnie. Wiadomości przesyłane za pośrednictwem kart pocztowych są bowiem wypierane przez elektroniczne narzędzia komunikacji wyposażone $\mathrm{w}$ funkcję sprawdzania pisowni, co utrudnia ustalenie, jaką pierwotną postać miały teksty tworzone $\mathrm{z}$ ich pomocą. Wydaje się jednak, iż zbadanie warstwy (orto)graficznej wiadomości przesyłanych na kartach pocztowych może wzbogacić wiedzę o praktyce piśmienniczej użytkowników języka rosyjskiego żyjących w drugiej połowie XX wieku.

\section{Bibliografia}

Алгазина Н. Н. 1987. Формирование орфографических навыков, Москва: Просвещение.

Алексеева А. А. 2014. Исследование текстов в социальной сети «Вконтакте» В лингводидактическом аспекте, "Лингвокультурология", nr 8, s. 6-10.

Вохмина Ю. С. 2015. Личностно ориентированные формы работы над ошибками на уроках русского языка $в 5$ классе средней общеобразовательной школы, „Педагогическое образование в России", nr 4, s. 77-84.

Иванова В. Ф. 1991. Современная русская орфография: учебное пособие, Москва: Высшая школа.

Кайдалова А. И., Калинина И. К. 1983. Современная русская орфография: учебное пособие для вузов по специальности «Журналистика», Москва: Высшая школа.

Крылов Ю. В. 2015. Нарушение норм языка в рекламном дискурсе (прием и антиприем), „Вестник Новосибирского государственного педагогического университета”, nr 2 (24), s. 161-171.

Лекант П. А. (red.) 1996. Современный русский цитературный язык, Москва: Высшая школа.

Малахов А. С. 2013. Русская диалектология: теория и практика. Учебное пособие, Владимир 2013: Издательство ВлГУ.

Немчинова Н. В. 2008. Корпоративная поздравительная открытка: коммуникативный и деловой аспект, „Известия Российского государственного педагогического университета имени А. И. Герцена", nr 12 (86), s. 217-221.

Немчинова Н. В. 2012. Лингвокогнитивное описание текста корпоративной поздравительной открытки, „Вестник Кемеровского государственного университета”, nr 4, s. 71-75.

Низеева Д. Р. 2014. Текстовое сопровождение поздравительных открыток (на материале немецикого языка), „Филология и культура", nr 36, s. 41-44.

Останина Ю. О. 2015. Система обучения орфографии на уроках русского языка $b$ 8-9-х классах, „Ученые записки Забайкальского государственного университета. Серия: Профессиональное образование, теория и методика обучения", nr 6 (65), s. $100-105$.

Пенкина С. Д., Коваленко Е. Г. 2016. Особенности работы над орфографическими ошибками в письменной речи младших школьников, „Символ науки”, nr 11, s. 165-168. 
Розенталь Д. Э. 1970. Вопросы русского правописания. Практическое руководство, Москва: Издательство МГУ.

Розенталь Д. Э. 1984. Прописная или строчная? Опыт словаря-справочника, Москва: Русский язык.

Розенталь Д. Э. 1988. Прописная или строчная? Словарь-справочник, Москва: Русский язык.

Тихонов А. Н. 1985. Словообразовательный словарь русского языка в двух томах, Москва: Русский язык.

Шарипова Н. Ю. 2013. Типология проявления дизорфографии у учащихся общеобразовательной школы, „Проблемы современного образования”, nr 2, s. 152-159.

Щербакова Н. Н. 2015. О роли лингвистической компетенции в формировании орфографического навыка, „Филологический класс", nr 2 (40), s. 35-36.

Cwejman T., Torzecka W. 1981. Zasady pisowni rosyjskiej i ćwiczenia ortograficzne, Warszawa: PWN.

Dulewiczowa I. 1993. Gramatyka konfrontatywna rosyjsko-polska. Fonetyka i fonologia. Grafia i ortografia, Warszawa: Slawistyczny Ośrodek Wydawniczy Omnitech Press.

Orzechowska S. 1994. Ćwiczenia z ortografii rosyjskiej z zasadami pisowni, cz. I: Ortografia, Wrocław: Wydawnictwo Uniwersytetu Wrocławskiego. 
